\author{
Mohamad Syahrul Nizam Ibrahim ${ }^{1}$, Mohd Ibrani Shahrimin Adam Assim² ${ }^{2}$, Shazali Johari \\ Syarifah Kamariah Wan Mohammad ${ }^{4}$, Suziana Hassan ${ }^{5}$ \\ ${ }^{1}$ PhD student of Universiti Putra Malaysia Bintulu Sarawak Campus \\ (Malaysia, Sarawak, Bintulu), e-mail: mohamadsyahrulnizamibrahim@gmail.com \\ ${ }^{2}$ PhD, Associate Professor, Universiti Putra Malaysia Bintulu Sarawak Campus \\ (Malaysia, Sarawak, Bintulu) \\ https://orcid.org/0000-0002-8836-9042 \\ ${ }^{3}$ PhD, Senior Lecturer, Universiti Putra Malaysia \\ (Malaysia, Selangor, Serdang), e-mail: Zali_johari@upm.edu.my \\ ${ }^{4}$ PhD, Senior Lecturer, Universiti Putra Malaysia Bintulu Sarawak Campus \\ (Malaysia, Sarawak, Bintulu), e-mail: k_syarifah@btu.upm.edu.my \\ https://orcid.org/0000-0003-1761-6138 \\ ${ }^{5}$ PhD, Senior Lecturer, Universiti Putra Malaysia Bintulu Sarawak Campus \\ (Malaysia, Sarawak, Bintulu),e-mail: suzi@upm.edu.my \\ https://orcid.org/0000-0002-1051-158X
}

\title{
PERCEPTION ON PENAN'S OROO' LANGUAGE AMONG LOCAL COMMUNITY AT BATU BUNGAN, MULU, SARAWAK, MALAYSIA
}

\begin{abstract}
Oroo' secret sign language is a medium that has been used to communicate in the forest among Penan community. It is threatened language and identified as living cultural heritage that has high potential to be promoted as a major tourism product in the World Heritage Site, Mulu. However, the local level appreciation on their cultural elements is a question that would have implications for this language to become extinct imminently. Thus, this study aims to examine perception on the importance of Oroo' language among Penan community at Batu Bungan. This exploration was conducted through a qualitative approach with personal interview with two Penans who are tribal chief and boatman who lived at the settlement. They were identified as key informants due to their active involvement and grown in the community. The narrative was analysed by thematic analysis deductively to elucidate their views on importance of Oroo' secret sign language in the community today. It was found that most young generation did not understand the language due to some factors. They perceived that Oroo' has no significant to their life because words are main medium of communication nowadays. While middle-aged community has at least basic knowledge of Oroo' from their self-experience with old-aged generation in the forest. The language is threatened with extinction due to its significant declining users. There is a need for relevant stakeholders to take actions towards preserving this intangible and unique cultural heritage.

Keywords. Oroo', Orang Ulu, Borneo, East Malaysia, endangered language.
\end{abstract}

\footnotetext{
*Бізге дұрыс сілтеме жасаңыз:

Mohamad Syahrul Nizam Ibrahim, Mohd Ibrani Shahrimin Adam Assim, Shazali Johari, Syarifah Kamariah Wan Mohammad, Suziana Hassan. 'A Curse or a Blessing?': the Fate of Iban Women in 'Adat Nguai' as Illustrated by Literary Devices in Iban Song Lyrics // Ясауи университетінің хабаршысы. - 2021. №4 (122). - Б. 27-36. https://doi.org/10.47526/2021-4/2664-0686.03

* Cite us correctly:

Mohamad Syahrul Nizam Ibrahim, Mohd Ibrani Shahrimin Adam Assim, Shazali Johari, Syarifah Kamariah Wan Mohammad, Suziana Hassan. 'A Curse or a Blessing?': the Fate of Iban Women in 'Adat Nguai' as Illustrated by Literary Devices in Iban Song Lyrics // Iasaui universitetinin habarshysy. - 2021. - №4 (122). - B. 27-36. https://doi.org/10.47526/2021-4/2664-0686.03
} 


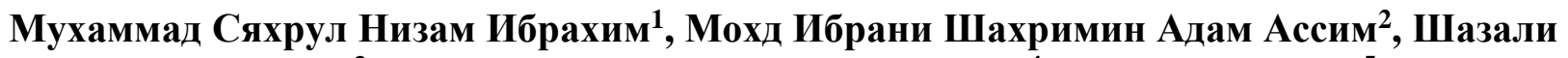
Джохари ${ }^{3}$, Сярифах Камариях Ван Мохаммад 4 , Сюзиана Хассан ${ }^{5}$

${ }^{1}$ PhD докторант, Путра Малайзия университеті, Бинтулу Саравак кампусы (Малайзия, Саравак, Бинтулу къ.), e-mail: mohamadsyahrulnizamibrahim@gmail.com

${ }^{2} \mathrm{PhD}$, доцент, Путра Малайзия университеті, Бинтулу Саравак кампусы (Малайзия, Саравак, Бинтулу к.)

${ }^{3} \mathrm{PhD}$, ава оқытушы, Путра Малайзия университеті (Малайзия, Селангор, Серданг қ..), e-mail: Zali_johari@upm.edu.my

${ }^{4} \mathrm{PhD}$, ава оқылтушы, Путра Малайзия университеті, Бинтулу Саравак кампусы (Малайзия, Саравак, Бинтулу к..), e-mail: k_syarifah@btu.upm.edu.my

${ }^{5} \mathrm{PhD}$, ава оқытушы, Путра Малайзия Университеті, Бинтулу Саравак кампусы (Малайзия, Саравак, Бинтулу к..), е-таil: suzi@upm.edu.my

\section{Бату Банан, Мулу, Саравак, Малайзиядағы жергілікті қоғамдастықтың ороо пенан тілін қабылдауы}

Андатпа. Ороо құпия ымдау тілі - бұл пенан қоғамдастығы арасында орманда сөйлесу үшін қолданылатын құрал. Бұл тіл жойылып кету қаупі бар және тірі мәдени мұра ретінде анықталған, Ол Мулу дүниежүзілік мұрасының негізгі туристік өнімі ретінде алға жылжу үшін жоғары әлеуетке ие. Алайда, олардың мәдени элементтерін Жергілікті деңгейде бағалау - бұл тілдің сөзсіз жойылып кетуіне әсер ететін мәселе. Осылайша, бұл зерттеудің мақсаты Бату Бунган қаласындағы пенан қоғамдастығы арасында ороо тілінің маңыздылығын түсінуді зерттеу болып табылады. Бұл зерттеу елді мекенде тұратын екі пенан, тайпа бастығы және қайықшымен жеке сұхбатпен сапалы тәсіл арқылы жүргізілді. Олар қоғамдастықтың белсенді қатысуы мен өсуіне байланысты негізгі ақпарат беруші ретінде анықталды. Әңгіме қазіргі қоғамдағы құпия ороо ымдау тілінің маңыздылығы туралы көзқарастарын нақтылау үшін дедуктивті тақырыптық талдау әдісімен талданды. Жас ұрпақтың көпшілігі кейбір факторларға байланысты тілді түсінбейтіні анықталды. Олар ороо олардың өмірінде маңызды емес екенін түсінді, өйткені бұл күндері сөздер қарымқатынастың негізгі құралы болып табылады. Орта жастағы қоғамдастық, ең болмағанда, ормандағы қарт адамдармен қарым-қатынас жасау тәжірибесінен ороо туралы негізгі білімге ие. Пайдаланушылар санының едәуір азаюына байланысты бұл тілге қауіп төніп тұр. Тиісті мүдделі тараптар осы материалдық емес және бірегей мәдени мұраны сақтау жөнінде шаралар қабылдауы қажет.

Кілт сөздер: ороо, Оранг Улу, Борнео, Шығыс Малайзия, жойылу қаупі бар тіл.

\section{Мухаммад Сяхрул Низам Ибрахим', Мохд Ибрани Шахримин Адам Ассим², Шазали Джохари ${ }^{3}$, Сярифах Камариях Ван Мохаммад ${ }^{4}$, Сюзиана Хассан $^{5}$ \\ ${ }^{1}$ PhD докторант, Университет Путра Малайзия, Кампус Бинтулу Саравак (Малайзия, Саравак, г. Бинтулу), e-mail: mohamadsyahrulnizamibrahim@gmail.com \\ ${ }^{2} \mathrm{PhD}$, доиент, Университет Путра Малайзия, Кампус Бинтулу Саравак \\ (Малайзия, Саравак, г. Бинтулу) \\ ${ }^{3} \mathrm{PhD}$, стариий преподаватель Университета Путра Малайзия \\ (Малайзия, Селангор, г. Серданг), e-mail: Zali_johari@upm.edu.my \\ ${ }^{4} \mathrm{PhD}$, старший преподаватель Университета Путра Малайзия, Кампус Бинтулу Саравак \\ (Малайзия, Саравак, г. Бинтулу), e-mail: k_syarifah@btu.upm.edu.my \\ ${ }^{5} \mathrm{PhD}$, старший преподаватель Университета Путра Малайзия, Кампус Бинтулу Саравак \\ (Малайзия, Саравак, г. Бинтулу), е-таil: suzi@upm.edu.my}

\section{Восприятие языка ороо пенана местным сообществом в Бату Бунган, Мулу, Саравак, Малайзия}


Аннотация. Секретный язык жестов ороо - это средство, которое использовалось для общения в лесу среди сообщества пенан. Этот язык находится под угрозой исчезновения и идентифицируется как живое культурное наследие, которое обладает высоким потенциалом для продвижения в качестве основного туристического продукта на объекте Всемирного наследия Мулу. Однако оценка на местном уровне их культурных элементов - это вопрос, который будет иметь последствия для неизбежного исчезновения этого языка. Таким образом, целью данного исследования является изучение восприятия важности языка ороо среди общины пенан в Бату-Бунгане. Это исследование было проведено с помощью качественного подхода с личным интервью с двумя пенанами, вождем племени и лодочником, которые жили в поселении. Они были определены в качестве ключевых информаторов благодаря их активному участию и росту в сообществе. Повествование было проанализировано методом дедуктивного тематического анализа, чтобы прояснить их взгляды на важность секретного языка жестов ороо в современном сообществе. Было установлено, что большинство молодого поколения не понимало язык из-за некоторых факторов. Они поняли, что ороо не имеет никакого значения в их жизни, потому что в наши дни слова являются основным средством общения. В то время как сообщество среднего возраста обладает, по крайней мере, базовыми знаниями об ороо из собственного опыта общения с поколением пожилых людей в лесу. Этот язык находится под угрозой исчезновения из-за значительного сокращения числа его пользователей. Соответствующим заинтересованным сторонам необходимо принять меры по сохранению этого нематериального и уникального культурного наследия.

Ключевые слова: ороо, Оранг Улу, Борнео, Восточная Малайзия, язык, находящийся под угрозой исчезновения.

\section{Introduction}

Malaysia is proud to have a unique cultural diversity that includes number of tribes in the province of Sarawak, Borneo. The Penan are a minority tribe known for their traditionally nomadic life and have the knowledge of navigation in the jungle of high intellectual value. Oroo' secret sign language is a medium that has been used to communicate in the forest among Penan community. This indigenous knowledge that is an element of the Penan culture and heritage that can be preserved so that it does not become extinct due to the passage of time.

Penan community in Mulu was settled in Batu Bungan and Long Iman in the early 1990s. This has prompted the government to establish several accesses to public facilities to the local community including primary school, church, and health clinic. Tourism has also boosted development in Mulu and indirectly provides many benefits to Penan's livelihood in Batu Bungan. However, this indigenous knowledge which is part of their culture are slowly not practiced and loss due to the change of lifestyle. According to (Rothstein, 2020), the cultural changes affect everybody, ranging from severe cognitive dissonance among certain elders, to less dramatic problems among the youth, which absolutely happened in Penan's native language nowadays.

Oroo' is a threatened language and identified as a living cultural heritage that has high potential to be promoted as a significant tourism product in the World Heritage Site, Mulu. However, the local level of appreciation on their cultural elements is a question that would have implications for this language to become extinct imminently. Thus, this study examines perception on the importance of Oroo's language among the Penan community at Batu Bungan.

\section{Literature Review}

\section{Indigenous knowledge}

Indigenous knowledge (IK) is the "knowledge that an indigenous (local) community accumulates over time (Averweg \& Greyling, 2010). This description of IK encompasses all forms 
of local knowledge acquired experientially - arts, languages, understanding, practices, technologies and beliefs - that enables a community to achieve stable livelihoods in its geographical residence". The IK is mainly tacit as stored in people's memories and organisational structures (Von Lewinski, 2008), implicit as embedded in people's daily lives and activities (Pettersen, 2011) and explicit as shared orally in stories, songs, folklores, and dances (Nyota \& Mapara, 2008). IK is non-formal, orally transmitted and usually not documented. It falls under tacit knowledge, which is personal knowledge, hard to put into words and is expressed through action (Jain \& Jibril, 2016). The domains of IK as illustrated by Frappaolo (2008) and Zaman, Kulathuramaiyer, et al. (2015) in Figure 1.

\section{Penan's indigenous knowledge}

Penan's knowledge and understanding of the Borneo rainforest is unique and unparalleled among Sarawak's indigenous groups (Zaman \& Falak, 2018). They, nomadic of the recent past, are live from farming today, but still depend on the forest for hunting and collecting various forest products. They have a detailed classification system for the plants and recognise many useful wild plants. Still, their use of knowledge is relatively simple and differs from that of other ethnic groups of Borneo (Koizumi \& Momose, 2007).
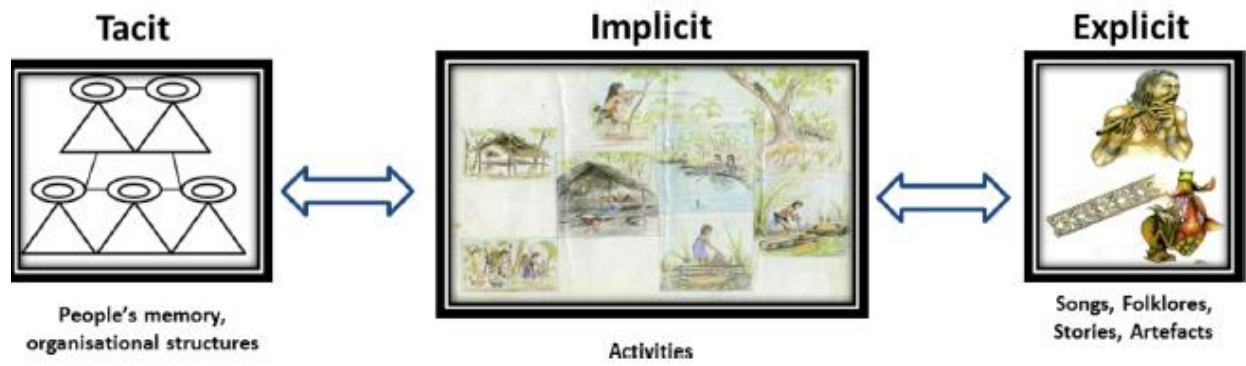

Figure 1 - Indigenous knowledge domains

Source: Frappaolo, (2008); Zaman, Kulathuramaiyer, et al. (2015).

In 2014, a research project in Long Lamai was initiated by Universiti Malaysia Sarawak with the community in Baram, one of the biggest and oldest settlements of the Penans on digitalising and preserving the Oroo's sign language. It is aimed to harness indigenous community's tacit and their creative expressions (Zaman et al., 2016; Zaman \& Winschiers-theophilus, 2017). It was found that the Penans have their cognitive maps of the jungle which are based on many sources as well as from Oroo' (Zaman, Winschiers-theophilus, et al., 2015) or Omen the signs and directions provided by the birds as pathfinders. However, the cognitive maps in the Penans minds are their tacit knowledge based, while the Oroo's sign language is explicit, and Omen are implicit beliefs.

\section{Research methods}

\section{Research permit and ethical approval}

This study has received official permission and approval from the Sarawak Forestry Corporation (reference number: SFC.PL\&RS/2020-005) which is complying to the National Parks and Nature Reserves Ordinance 1998. Besides, the approval of the University Ethics Committee for Research Involving Humans (JKEUPM) (reference number: JKEUPM-2020-403) was received for its compliance with the Declaration of Helsinki and International Conference of Harmonization (ICH Guidelines), Good Clinical Practice (GCP) Standards, Council for Organizations of Medical Sciences (CIOMS) Guidelines, World Health Organization (WHO) Standards and Operational Guidance for Ethics Review of Health-Related Research and Surveying and Evaluating Ethical Review Practices, EC/ IRB Standard Operating Practices (SOPs), and Local Regulations and Standards in Ethical Review. The informed consent was obtained from the participants in this study and the protocol was approved by the JKEUPM. 


\section{Research area}

The study was conducted at Penan settlement, Kampung Batu Bungan, Mulu, Sarawak, Malaysia (4³'11.956" N, 114²9'8.282" E) (Figure 2) in April 2021. The Sarawak Government initiated the settlement in the early 1990s as a service center to bring the Penans out of their nomadic way of life and to facilitate assistance to them. The settlement has become part of the attraction of the world-renowned national park. Most of the local community work as park staff, boat and handicraft operators as well as farmers. The handicraft entrepreneurs are women, and they sell the forest product at the Batu Bungan Craft Market which is a must-visit place for tourists. The Penan are better known for their fine handicrafts and only their community markets the handicraft products in Mulu, namely at the Batu Bungan and Long Iman Craft Markets.

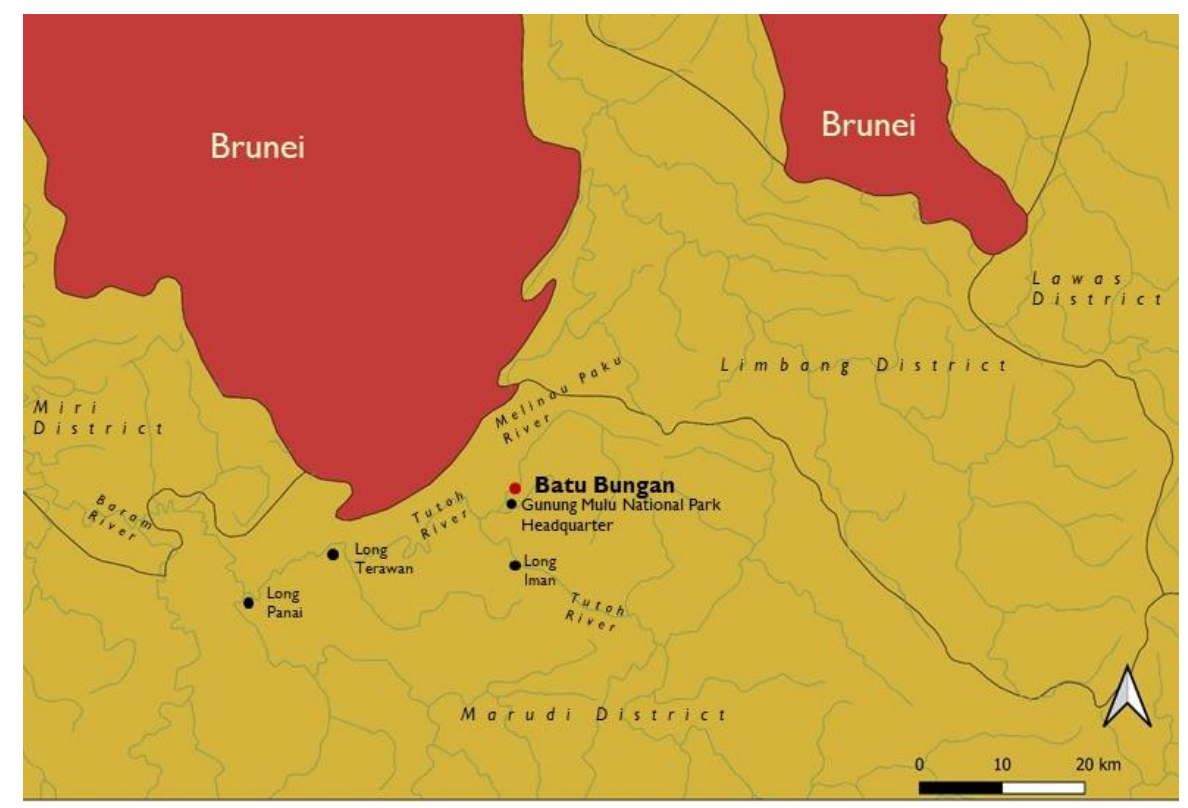

Figure 2 - Location of research area, Kampung Batu Bungan, Mulu, Sarawak, Malaysia

\section{Key informants' interview}

This exploration was conducted through a qualitative approach with a personal interview with two Penans who are tribal chief and boatman lived at the settlement. An interview session was conducted on key informant 1 (K1) in the Malay language with the help of a Malay-Penan interpreter for convenience and better response. Meanwhile, another interview with key informant 2 (K2) were carried out without interpreter because he could interact well in the national language.

They were identified as key informants due to their active involvement and grown in the community. Their narratives provide a qualitative aspect which has meaning, significance and rich understanding (Tashakkori et al., 2020). The key informants involved are two individuals that are available during the study. This limitation is caused by the pandemic, where many locals chose to stay in the jungle as they were afraid of the COVID-19 pandemic infection that was likely to be carried by outsiders. Thus, it was quite challenging to get more key informants for interview purpose. The number of key informants $(n=2)$ are acceptable for qualitative approach which its nature is require a small sample size. According to (Hammarberg et al., 2016), larger sample sizes are not more applicable because the depth may be sacrificed the scope, or excessive data for rigorous analysis. The key informant voices help to achieve data saturation, external validity, and/or information redundancy (Onwuegbuzie and Leech, 2007). Table 1 presented to show the characteristics of two key informants interviewed in different sessions. 
Table 1 - List of key informants interviewed in different sessions

\begin{tabular}{ccccc}
\hline $\begin{array}{c}\text { Key } \\
\text { informant } \\
(\text { K })\end{array}$ & Age & Generation & Gender & Occupation \\
\hline 1 & 62 & Old-aged & Male & Tribal chief \\
2 & 52 & Middle-aged & Male & Boatman \\
\hline
\end{tabular}

\section{Data analysis}

The narrative was analysed by thematic analysis deductively to elucidate their views on importance of Oroo' secret sign language in the community today. It was transcribed, coded, themed (categorised), validated and interpreted in accordance with Talib (2019). Finally, it was facilitated by Computer Aided Qualitative Data Analysis (CAQDAS), specifically ATLAS.ti 8 Windows.

\section{Results and discussion}

There are several key informants' views on the status and level of knowledge of the Oroo' sign language among Penan's communities in Mulu, including Kampung Batu Bungan and Kampung Long Iman.

Oroo' language as a medium of communication in the forest

"Oroo' is a language commonly used by previous generations of Penan for communication purposes in the forest such as navigation using signs from tree twigs and leaves". (K1)

The arrangement of the twigs and leaves describes the combination of words in a sentence. The message can be translated if the individual understands each word that is trying to be conveyed. Oroo' is the object of writing language used by earlier generations to leave messages for each other in the jungle (Jensen, 1970). Sticks, prepared with cuts, twigs, and leaves in certain positions and places, will guide people, and inform them about directions, time, dangers, resources, etc. (Rothstein, 2020).

\section{Oroo's language as a cultural element and less practical to use nowadays}

According to K1, the Oroo' language is only part of the customs and culture and can still be understood by many people, especially the older generation. However, the language is poorly understood among average younger generation. It is because they have received a formal education in school and can read and write well. Thus, the importance of mastering the Oroo' language has become less significant for them. Furthermore, the language is rarely used and is considered an ancient language. Similarly, based on a study by Plimmer et al. (2015), it was found that the language has disappeared and is no longer used by the younger generation among Penans in Long Lamai since they were settled.

According to UNESCO (2011), the loss of indigenous languages is also detrimental to biodiversity, as traditional knowledge of nature and the universe, spiritual beliefs and cultural values expressed in indigenous languages provide time-tested mechanisms for the sustainable use of natural resources and management of ecosystems. These elements have become more critical with the emergence of urgent new challenges posed by climate change.

Informal lessons from elder generation

Figure 3 shows K2 was explaining the basic Oroo' language which indicates that the Penan community uses twigs and leaves to form specific signals that carry certain messages. This clear explanation shows that a middle-aged generation is good at the Oroo' language. It further to supports the statement of $\mathrm{K} 1$ that the middle-aged generation can still understand the language very well as compared to the young-aged generation (born in the 90s or later). It is in line with Zaman et 
al. (2014) where the respondents who over the age of 60 have mastered the language because they experienced a nomadic life when they were young (Zaman et al., 2014).

K2 stated that he had learned the Oroo' language through experiences with his father when hunting in the forest and looking for sago since childhood. He was accustomed to wading through the forest for that purpose and work of cutting and carrying trees, removing obstacles along the way in the forest.

"We did not have formal classes to learn this Oroo' language. We are indirectly good at using that language." (K2)

However, according to K2, some Penan's younger generation who live with their families and semi-nomads in the jungle, are still able to use the language compared to the community in Kampung Batu Bungan.

"My 11-years-old son is already good at using sumpit (blowgun). He is good at using poison for hunting purposes because he always follows me to the forest, and I taught him." (K2)

In conclusion, this informal lesson has the most crucial value in the Penan community. The Oroo' are themselves expressions of social interaction. Given the fact that people usually travel together, the reading and interpretation of the signs is also a social practice, although often the meaning of Oroo' is rather explicit (Rothstein, 2020).
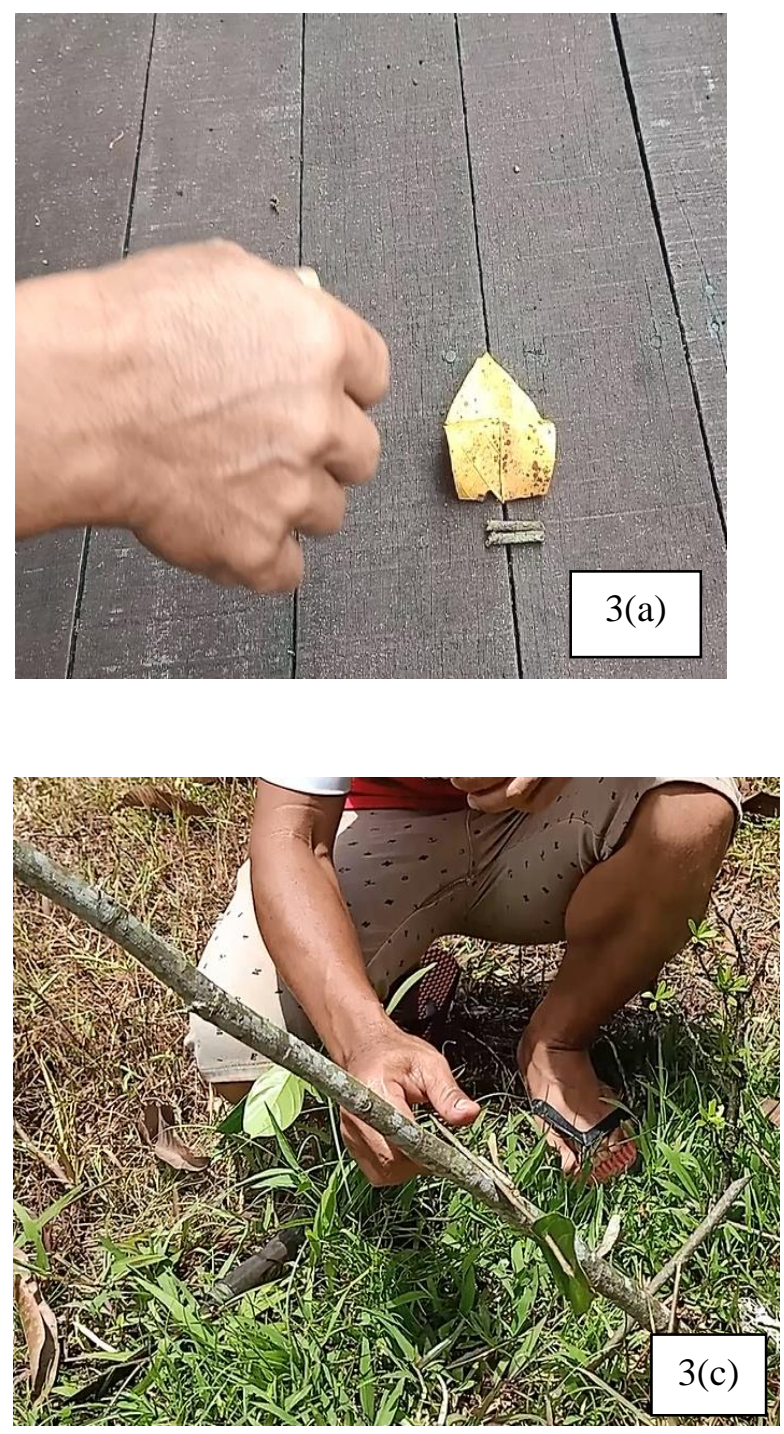

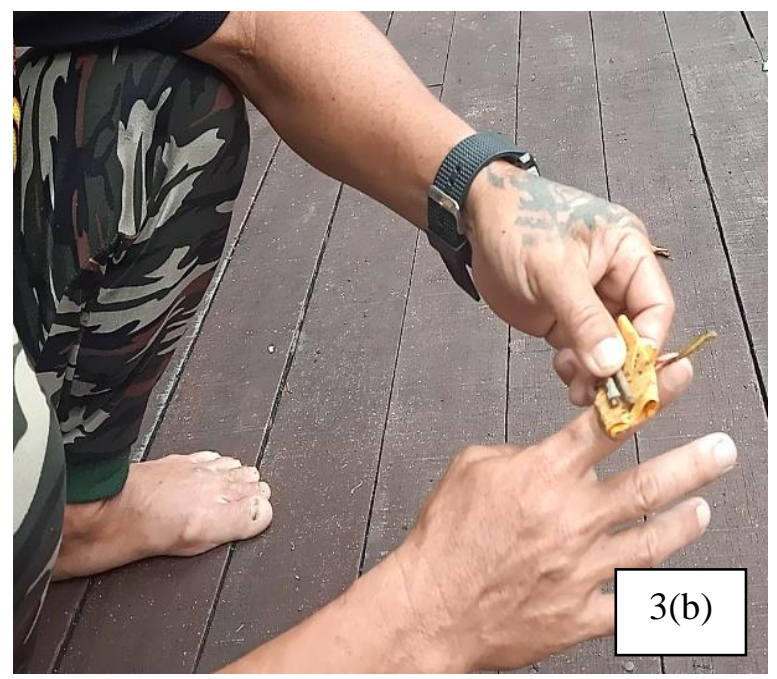

Figure 3 (a) - The symbol of two twigs of the same length indicates the presence of a team/ one/ friend/ family (non-enemies) while in the forest;

Figure 3(b) - The two twigs placed on top of the folded leaves indicate hunger signals to non-enemies (friends, family, acquaintances);

Figure 3(c) - The combination of the symbol of a leaf pricked by a small twig, then inserted with a tree branch carries the meaning that the individual has obtained the hunted animal (wild boar or other foods) in this straight direction 
Younger generation knowledge and practices

"Most young people do not understand Oroo' language, especially those born in their 90s and above" (K2).

The elders realized that Oroo' will be lost if they do not find ways to preserve and pass it through the younger generations (Plimmer et al., 2015).

$\mathrm{K} 2$ also informed that their previous lives were more difficult, and younger generation is lack of interest to go into the forest. Some were afraid to go into the woods, unlike the middle age who had experienced and were trained for it.

Furthermore, as mentioned by K1 earlier, words have become the primary medium of communication in society nowadays, and it affects the Oroo 'language to be less important. The times and lifestyles slowly changed, and they adapted to the new situation. Indirectly formal education and socioeconomic factors caused this transformation to take place.

Implications of the COVID-19 pandemic on local livelihood and Oroo' language

Due to the pandemic, the tourism sector has stagnated for a while. As a result, local people have lost their source of income due to the lack of tourists. Furthermore, K1 also stated that a handful of villagers are chosen to stay in the forest to avoid COVID-19 virus infection. Penan community in Kampung Long Iman hid and ran away from home when medical officers came to their village to perform a covid-19 polymerase chain reaction swab test (Nais, 2021).

The increasing number of COVID-19 infection cases every day is likely to cause many individuals to move to the forest. On the positive side, they can spend time together in the woods. This further strengthens the family bond and indirectly, they engage in traditional lifestyle that practiced by earlier generation. It is possible that young-aged generation to have the opportunity learn and experience the Oroo' language from the middle-aged.

\section{Conclusion}

Most young generation did not understand the language due to some factors. They perceived that Oroo' has no significance towards their life. While middle-aged community has at least basic knowledge of Oroo' from their self-experience with old age generation in the forest. The language is threatened with extinction due to its significant declining speakers.

Although the younger generation is more familiar with technology than engaging with their surrounding forest, it is not a reason for the language to continue to be threatened with extinction. There was an initiative by Plimmer et al., (2015) and Zaman et al. (2016) in digitizing the language in the form of game applications that are more interactive to the younger generation, namely children as a form of reintroduction to their culture. The game application requires indigenous wisdom from its players. This will make children to ask their parents to play in the game and it is seen as a good thing which encourages intergenerational knowledge transfer towards supporting the preservation of this language. Younger generation can teach the middle-aged and old-aged generation to use the technology in line with the passage of time. This will also strengthen their family ties like previous generations.

From this conducted study, it is recommended to stakeholders to take actions in preserving this intangible and unique cultural heritage. Relevant stakeholders can promote this cultural element as a significant tourism product in the Gunung Mulu National Park in addition to the biodiversity richness in this world-renowned area. In this effort, it is suggested that the language should be documented through interactive publications such as books and brochures so that tourists know this cultural heritage of the Penan tribe are unique in Malaysia.

In addition, the park guide, boatman, accommodation operator, and craft operator who are from the Penan community are ambassadors that are responsible in promoting the culture to tourists. It can enhance tourists experience in Mulu and will motivate them to revisit and spread it to other people. The value of appreciation for cultural elements can be nurtured through this memorable experience. Memorable tourism experiences play a key role in obtaining tourist's 
satisfaction and loyalty in sustaining the tourism destination (Subramaniam et al., 2019; Arpentieva et al., 2021).

Oroo' language, which is the explicit domain of IK, is very significant to be courted so that it does not extinct due to the passes of the times. Like other indigenous languages in Sarawak, Oroo' also needs to be highlighted by stakeholders for social sustainability.

\section{Acknowledgements}

The authors would like to thank Sarawak Forestry Corporation and Borsarmulu Park Management Sdn. Bhd. for permission and cooperation to conduct the study in this area successfully. The approval of the University Ethics Committee for Research Involving Humans (JKEUPM) is much appreciated. We would like to thank Kampung Batu Bungan community for involving as respondents in this study. Special thanks are also due to Mr. Modin anak Ambau, Miss Erra Fazira Abdul Rahim, Mr. Farhan Ismat and those who contributed directly or indirectly in the completion of this study.

\section{REFERENCES}

1. Arpentieva M.R..; Retnawati H.; Akhmetova T.A.; Azman M.N.A.; Kassymova G.K. (2021). Constructivist approach in pedagogical science. Challenges of Science. Issue IV, 2021, pp. 1217. https://doi.org/10.31643/2021.02

2. Averweg, U.R., \& Greyling, E. H. (2010). Some challenges for Information and Communication Technologies in Indigenous Knowledge preservation. Journal of the Southern Africa Institute of Management Services (SAIMAS), 19(1), 15-17. http://www.ulwazi.org/docs/Averweg and Greyling 10th June 2010.pdf

3. Frappaolo, C. (2008). Implicit knowledge. Knowledge Management Research \& Practice, 6(1), 23-25. https://doi.org/10.1057/palgrave.kmrp.8500168

4. Hammarberg, K., Kirkman, M., \& Lacey, S. De. (2016). Qualitative research methods : when to use them and how to judge them. 31(3), 498-501. https://doi.org/10.1093/humrep/dev334

5. Jain, P., \& Jibril, L. (2016). Expanding Library Services for Indigenous Community Posteriy: A Case of Selected Public Libraries in Botswana. The IFLA World Library and Information Congress, 1-19.

6. Jensen, H. (1970). Sign, symbol and script: An account of man'sefforts to write. Allen \& Unwin.

7. Koizumi, M., \& Momose, K. (2007). Penan Benalui wild-plant use, classification, and nomenclature. Current Anthropology, 48(3), 454-459. https://doi.org/10.1086/517593

8. Nais, N. (2021, July 2). Penan villagers went into hiding, fled homes to avoid Covid-19 swab tests in Long Iman. Dayak Daily. https://dayakdaily.com/penan-villagers-went-into-hidingfled-homes-to-avoid-covid-19-swab-tests-in-long-iman/

9. Nyota, S., \& Mapara, J. (2008). Shona Traditional Children's Games and Play: Songs as Indigenous Ways of Knowing. The Journal of Pan African Studies, 2(4), 189-203.

10. Onwuegbuzie, A.J., \& Leech, N.L. (2007). Sampling designs in qualitative research: making the sampling process more public. The Qualitative Report, 12(2), 19-20.

11. Pettersen, B. (2011). Mind the digital gap: Questions and possible solutions for design of databases and information systems for Sami traditional knowledge. In Working with Traditional Knowledge: Communities, Institutions, Information Systems, Law and Ethics (Issue 1, pp. 163-192). Sámi University College.

12. Plimmer, B., He, L., Zaman, T., Karunanayaka, K., Yeo, A.W., Jengan, G., Blagojevic, R., \& Do, E. Y. (2015). New Interaction Tools for Preserving an Old Language. The 33rd Annual ACM Conference on Human Factors in Computing Systems, 3493-3502.

13. Rothstein, M. (2020). Being lost Landscape, troubling spirits and ritual strategies among the 
Eastern Penan. Hunter Gatherer Research, 4(3), 355-368. https://doi.org/10.3828/hgr.2018.22

14. Subramaniam, T., Samdin, Z., Ramachandran, S., \& Kunasekaran, P. (2019). Memorable Ecotourism Experiences in Taman. International Journal of Recent Technology and Engineering (IJRTE), 7(5S), 25-33.

15. Talib, O. (2019). Analisis data kualitatif dengan Atlas.ti (1st ed.). Penerbit Universiti Putra Malaysia.

16. Tashakkori, A., Johnson, R. B., \& Teddlie, C. (2020). Foundations of Mixed Methods Research: Integrating Quantitative and Qualitative Approaches in the Social and Behavioral Sciences (2nd ed.). SAGE Publications, Inc.

17. UNESCO. (2011). Atlas of the World's Languages in Danger (C. Moseley (ed.); 3rd ed.). UNESCO.

18. Von Lewinski. (2008). Indigenous heritage and intellectual property: genetic resources,traditional knowledge and folklore (2nd ed.). Kluwer Law International.

19. Zaman, T., \& Falak, H. (2018). Insights and Challenges in Digitalization of a Secret Sign Language of the Penan on Borneo Island. Springer Singapore. https://doi.org/10.1007/978-98110-7697-8

20. Zaman, T., Kulathuramaiyer, N., Yeo, A. W., \& Falak, H. (2015). Modelling indigenous knowledge creation as a living system. 6(2), 136-150.

21. Zaman, T., \& Winschiers-theophilus, H. (2017). Penan's Oroo' Short Message Signs (PO-SMS ): Co-design of a Digital Jungle Sign Language Application. 15th Human-Computer Interaction (INTERACT), 489-504.

22. Zaman, T., Winschiers-theophilus, H., \& Yeo, A. W. (2015). Reviving an Indigenous Rainforest Sign Language : Digital Oroo 'Adventure Game. 15-18.

23. Zaman, T., Yeo, A. W., \& Jengan, G. (2016). Designing digital solutions for preserving penan sign language: A reflective study. Advances in Human-Computer Interaction, 2016. https://doi.org/10.1155/2016/4174795

24. Zaman, T., Yeo, A.W., \& Kulathuramaiyer, N. (2014). Knowledge Management in Nonprofit Settings: A Case Study of Indigenous Knowledge Management. International Journal of Public Administration in the Digital Age (IJPADA), 1(4), 8. 